\title{
HUBUNGAN ANTARA PEKERJAAN DAN PENDIDIKAN TERHADAP RENDAHNYA KEIKUTSERTAAN SUAMI MENJADI AKSEPTOR KB PRIA DI WILAYAH KERJA PUSKESMAS TALANG BETUTU PALEMBANG TAHUN 2017
}

\author{
Nelly Mariyam ${ }^{1}$, Ria Oktaviani ${ }^{2}$ \\ 1. Dosen prodi D III Kebidanan STIK Siti Khadijah Palembang \\ 2. STIK Siti Khadijah Palembang \\ nellymariyam88@gmail.com \\ riaoktaviani@gmail.com
}

\begin{abstract}
ABSTRAK
Partisipasi pria untuk mengikuti program KB masih rendah. Salah satunya disebabkan minimnya akses laki-laki terhadap perolehan informasi, pelayanan $\mathrm{KB}$, dan kesehatan reproduksi. Tujuan penelitian ini untuk mengetahui hubungan pekerjaan dan pendidikan terhadap rendahnya keikutsertaan suami menjadi akseptor KB pria di Wilayah Kerja Puskesmas Talang Betutu Palembang tahun 2017. Desain penelitian Kuantitatif bersifat Survei Analitik dengan pendekatan Cross Sectional, populasi pada penelitian ini adalah seluruh akseptor KB pria dari bulan Januari - Mei yang berjumlah 106 orang tercatat didalam Rekam Medik di Puskesmas Talang Betutu Palembang Tahun 2017, dengan pengambilan sampel menggunakan teknik Simple Random Sampling yang berjumlah 51 orang dan alat ukur yang digunakan adalah Cheklist. Analisis data meliputi univariat dan bivariat dengan menggunakan Chi-Square. Hasil uji statistik didapatkan bahwa terdapat hubungan antara pekerjaan terhadap rendahnya keikutsertaan suami menjadi akseptor $\mathrm{KB}$ pria dengan $p$ value 0,036 , hubungan antara pendidikan terhadap rendahnya keikutsertaan suami menjadi akseptor KB pria dengan $p$ value 0,006 Berdasarkan hasil penelitian ini disarankan kepada Puskesmas Talang Betutu Palembang untuk meningkatkan penyuluhan kesehatan khususnya tentang Kontrasepsi Pria dan pentingnya ber-KB.
\end{abstract}

\section{ABSTRACT}

The participation of men to follow the family planning program is still low. One of them is due to the lack of men's access to information acquisition, family planning services, and reproductive health. The aim of this study was to determine the relationship between job, education, and low participation number of husband to be KB acceptor around Talang Betutu public health center Palembang in 2017. Quantitative research design is an Analytical Survey with Cross Sectional approach, population in this study are all male KB acceptor from January - May totaling 106 people recorded in the Medical Record at Talang Betutu Palembang Health Center in 2017, with sampling using Simple Random Sampling technique amounting to 51 people and measuring instruments used are Cheklist. Data analysis included univariate and bivariate using Chi-Square. The result of statistical test shows that there is a relation between work on the low participation of husband become male family planning acceptor with $\mathrm{p}$ value 0,036 , and that there is a relation between education on the low participation of husband become male family planning acceptor with p value 0,006 . Based on the result of this research, it is suggested to Talang Betutu Palembang Health Center to improve health education especially about Male Contraception and the importance of family planning. 


\section{PENDAHULUAN}

Keluarga Berencana (KB) merupakan salah satu pelayanan kesehatan preventif yang paling dasar dan utama bagi wanita, meskipun tidak selalu diakui demikian. Peningkatan dan perluasan pelayanan keluarga berencana merupakan salah satu usaha untuk menurunkan angka kesakitan dan kematian ibu yang sedemikian tinggi akibat kehamilan yang dialami oleh wanita. Banyak wanita harus menentukan pilihan kontrasepsi yang sulit, tidak hanya karena terbatasnya jumlah metode yang tersedia tetapi juga karena metode-metode tertentu mungkin tidak dapat diterima sehubungan dengan kebijakan nasional $\mathrm{KB}$, kesehatan individual dan seksualitas wanita atau biaya untuk memperoleh kontrasepsi (BKKBN, 2015).

Menurut WHO (2011), kesetaraan dan keadilan gender dalam keluarga berencana telah menjadi salah satu strategi utama dalam pelaksanaan program KB didunia. Di Amerika Serikat, data yang ada menunjukkan bahwa kaum pria lebih memiliki antusias untuk berperan serta dalam keluarga berencana, dimana peserta yang menggunakan kondom sebesar 13\% dan lebih dari $15 \%$ memilih melakukan MOP.

Hasil Survei Demografi dan Kesehatan Indonesia (SDKI) (2011) menunjukkan partisipasi pria untuk mengikuti KB masih rendah. Persentase tertinggi pemakaian kondom hanya mencapai 1,3 persen, sedangkan vasektomi belum pernah mencapai satu persen sejak 1991. Berdasarkan data BKKBN Tahun 2011 pencapaian akseptor KB pria baru yang tertinggi berada di Propinsi Jawa Tengah yaitu 29.727 akseptor $(0,44 \%)$, yang terendah di Propinsi Gorontalo yaitu 607 akseptor $(0,01 \%)$, dan Sumatera Utara berada telah mencapai $0,3 \%$ (22.161 akseptor) dari total 6.799.819 akseptor KB pria baru di Indonesia $(3,25 \%)$. Padahal, perkiraan permintaan masyarakat (PPM) nasional yang ditargetkan, partisipasi pria dalam ber-KB adalah 4,5\% dari seluruh akseptor.

Berdasarkan Dinas Kesehatan Provinsi Sumatera Selatan, jumlah cakupan peserta KB aktif tahun 2013 sebesar 927.561 orang, tahun 2014 sebesar 1.205.207 orang. Peserta KB aktif tertinggi pria yang ada di Sumatera Selatan sebanyak 0,77\%, sedangkan peserta KB Dengan demikian jumlah PUS yang ada di Provinsi Sumatera Selatan tidak sesuai dengan keikutsertaann suami menjadi akseptor KB pria. (Dinas Kesehatan Provinsi Sumatera Selatan, 2014).

Berdasarkan laporan dari Dinas Kesehatan Kota Palembang, pada tahun 2012 jumlah PUS ( Pasangan Usia Subur ) sebesar 246.954 orang, dan peserta aktif KB pria 959 orang $(0,38 \%)$. Pada tahun 2013 jumlah PUS 262.668 orang, dan peserta aktif KB pria sebanyak 562 orang $(0,21 \%)$. Pada tahun 2014 jumlah PUS sebesar 305.548 orang dan peserta aktif KB pria sebanyak 18.957 orang $(6,2 \%)$. Pada tahun 2015 jumlah PUS sebesar 305.548 orang dan peserta aktif KB sebanyak pria 6.406 orang $(2,0 \%)$ (Profil Dinas Kesehatan Kota Palembang, 2015).

Secara pencapaian kinerja BKKBN Sumatera Selatan cukup memuaskan dengan melampaui target sebesar 104\% untuk penambahan peserta KB baru pada 2016. Sumatera Selatan masuk dalam kategori rapor merah karena berada diatas nasional. Target BKKBN menurunkan angka (TFR) dari 2,8\% menjadi 2,4\% yakni jumlah anak yang lahir yakni lebih dari dua orang tapi tidak mencapai tiga orang dapat tercapai. Berdasarkan data BKKBN 
Sumatera Selatan diketahui jumlah PLKB hanya 498 orang untuk menangani 3000an desa 1:5.

Rendahnya tingkat partisipasi pria dalam menggunakan alat kontrasepsi dipengaruhi oleh banyak faktor seperti pekerjaan, pendidikan, sosial budaya, agama. Ekonomi, geografi serta pangetahuan pria PUS terhadap kontrasepsi. Factor-faktor yang mempengaruhi rendahnya keikutsertaan suami menjadi akseptor KB adalah pekerjaan, pendidikan, social budaya, dan pengetahuan (Saifuddin, 2010).

Hasil penelitian Erna di Puskesmas Sedayu II pada tahun 2015 dari bulan Januari sampai dengan bulan November didapatkan 170 akseptor KB antara lain akseptor akseptor suntik 41,7\%, akseptor IUD 24,7\%, akseptor implant 17,6\%, akseptor pil 12,9\%, akseptor kondom $1,76 \%$ orang dan akseptor MOW 1,17\% dan akseptor MOP 0,02\%.

Berdasarkan data yang di peroleh dari Puskesmas Talang Betutu Palembang, bahwa suami yang sudah ikut serta dalam penggunaan alat kontrasepsi pada tahun 2014 kontrasepsi kondom sebanyak 66 orang $(90,4 \%)$, dan kontasepsi mantap sebanyak 7 orang $(9,5 \%)$, pada tahun 2015 kontrasepsi kondom sebanyak 109 orang $(94,7 \%)$, dan kontrasepsi mantap sebanyak 6 orang (5,2\%), dan pada tahun 2016 kontrasepsi kondom sebanyak 129 orang (100\%), dan kontrasepsi mantap 0 orang (0\%), dan pada tahun 2017 pada bulan Januari sampai Mei kontrasepsi kondom sebanyak 100 orang $(94,3 \%)$ dan kontrasepsi mantap sebanyak 6 orang (5,6\%) (Dokumentasi Puskesmas Talang Betutu Palembang, 2016).

\section{Tujuan Penelitian}

Tujuan Umum Diketahui hubungan antara pekerjaan dan pendidikan terhadap rendahnya keikutsertaan suami menjadi akseptor KB. Sedangkan tujuan khusus diketahui distribusi frekuensi keikutsertaan suami menjadi akseptor KB, diketahui distribusi frekuensi pekerjaan suami menjadi akseptor $\mathrm{KB}$, diketahui distribusi frekuensi pendidikan suami menjadi akseptor KB, diketahui hubungan antara pekerjaan suami dengan keikutsertaan suami menjadi akseptor KB, diketahui hubungan antara pendidikan suami dengan keikutsertaan suami menjadi akseptor KB.

\section{Metode Penelitian}

Penelitan ini menggunakan survey analitik dengan menggunakan teknik cross sectional dimana variabel independen yaitu Pekerjaan dan Pendidikan dan variabel dependen yaitu Rendahnya keikutsertaan suami menjadi akseptor KB diambil pada waktu yang bersamaan. Survey analitik adalah penelitian yang mencoba menggali bagaimana dan mengapa fenomena kesehatan itu terjadi. Sampel dalam penelitian ini dilakukan dengan menggunakan teknik simple random sampling yaitu pengambilan sampel dengan acak tanpa memperhatikan strata yang ada dalam anggota populasi. Rumus besaran sampel dalam Notoatmodjo 2012 sebagai berikut :

$$
\begin{gathered}
n=\frac{106}{1+106(0,01)} \\
n=51,4
\end{gathered}
$$

Jadi, jumlah sampel yang akan diteliti berjumlah 51 orang.

Cara pengambilan sampel :

a. Dengan cara undian/arisan 


\section{Hasil Penelitian}

Tempat penelitian ini adalah di Wilayah Kerja Puskesmas Talang Betutu Palembang dimana wilayah ini terdiri dari 3 desa yaitu, Talang Betutu, Talang Jambe, Sukodadi. Pada tahun 2016, jumlah penduduk di Wilayah Kerja Puskesmas Talang Betutu adalah 49.192 jiwa, yang tersebar di tiga Kelurahan yang terdiri dari 24.476 orang penduduk berjenis kelamin perempuan dan 24.716 penduduk berjenis kelamin laki-laki.

\section{1) Analisa Univariat}

\section{Tabel 1}

Distribusi Frekuensi Responden Berdasarkan Keikutsertaan Suami Menjadi Akseptor KB Pria di Wilayah Kerja Puskesmas Talang Betutu Palembang Tahun 2017

\begin{tabular}{|l|l|l|l|}
\hline No & $\begin{array}{l}\text { Keikutsertaan suami menjadi } \\
\text { akseptor KB pria }\end{array}$ & Frekuensi & Persentase(\%) \\
\hline 1 & Kondom & 45 & $88,2 \%$ \\
\hline 2 & Vasektomi & 6 & $11,8 \%$ \\
\hline Total & 51 & $100 \%$ \\
\hline
\end{tabular}

Dari tabel 1 diatas dapat dilihat dari 51 responden bahwa responden yang memilih menjadi akseptor KB Pria Kondom sebanyak $45(88,2 \%)$ responden lebih banyak dibandingkan yang memilih menjadi akseptor KB Pria Vasektomi sebanyak $6(11,8 \%)$ responden.

Tabel 2

Distribusi Frekuensi Responden Berdasarkan Pekerjaan di Wilayah Kerja Puskesmas Talang Betutu Palembang Tahun 2017

\begin{tabular}{|l|l|l|l|}
\hline No & Pekerjaan & Frekuensi & Persentase(\%) \\
\hline 1 & Bekerja & 30 & 58,8 \\
\hline 2 & Tidak bekerja & 21 & 41,2 \\
\hline \multicolumn{2}{|l|}{ Total } & 51 & $100 \%$ \\
\hline
\end{tabular}

Dari tabel 2 Diatas dapat dilihat bahwa responden yang bekerja sebanyak 30
$(58,8 \%)$ responden lebih banyak dari yang tidak bekerja $21(41,2 \%)$ responden.

Tabel 3

Distribusi Frekuensi Responden Berdasarkan Pendidikan di Wilayah Kerja Puskesmas Talang Betutu Palembang Tahun 2017

\begin{tabular}{|l|l|l|l|}
\hline No & Pendidikan & Frekuensi & Persentase $(\%)$ \\
\hline 1 & Tinggi & 23 & 45 \\
\hline 2 & Rendah & 28 & 55 \\
\hline \multicolumn{2}{|l|}{ Total } & 51 & $100 \%$ \\
\hline
\end{tabular}


Dari tabel 3 Dapat dilihat bahwa responden yang berpendidikan tinggi sebanyak $23(45 \%)$ responden lebih sedikit dari yang berpendidikan rendah $28(55 \%)$ responden.

\section{2) Analisa Bivariat}

Tabel 4

Hubungan Pekerjaan Suami dengan Keikutsertaan Suami menjadi Akseptor KB Pria di Wilayah Kerja Puskesmas Talang Betutu Palembang Tahun 2017

\begin{tabular}{|c|c|c|c|c|c|c|c|c|}
\hline \multirow[t]{3}{*}{ No } & \multirow[t]{3}{*}{ Pekerjaan } & \multicolumn{4}{|c|}{ Keikutsertaan suami menjadi akseptor KB pria } & \multirow{2}{*}{\multicolumn{2}{|c|}{ Jumlah }} & \multirow{3}{*}{$\begin{array}{l}p \\
\text { value }\end{array}$} \\
\hline & & \multicolumn{2}{|c|}{ Kondom } & \multicolumn{2}{|c|}{ Vasektomi } & & & \\
\hline & & $\mathrm{N}$ & $\%$ & $\mathrm{~N}$ & $\%$ & $\mathrm{~N}$ & $\%$ & \\
\hline 1 & Bekerja & 24 & 80 & 6 & 20 & 30 & 100 & \multirow{3}{*}{0,036} \\
\hline 2 & Tidak bekerja & 21 & 100 & 0 & 0 & 21 & 100 & \\
\hline \multicolumn{2}{|c|}{ Total } & 45 & 88,2 & 6 & 11,8 & 51 & 100 & \\
\hline
\end{tabular}

Berdasarkan hasil Uji Chi-Square untuk variabel pekerjaan suami yang didapatkan $p$ value $(0,036) \leq \alpha(0,05)$, hal ini menunjukan bahwa secara statistik ada hubungan yang bermakna antara pekerjaan suami dengan keikutsertaan suami menjadi akseptor KB pria di Wilayah Kerja Puskesmas Talang Betutu Palembang Tahun 2017.

Tabel 5

Hubungan Pendidikan Suami dengan Keikutsertaan Suami menjadi Akseptor KB Pria di Wilayah Kerja Puskesmas Talang Betutu Palembang Tahun 2017

\begin{tabular}{|c|c|c|c|c|c|c|c|c|}
\hline \multirow[t]{3}{*}{ No } & \multirow[t]{3}{*}{ Pendidikan } & \multicolumn{4}{|c|}{ Keikutsertaan suami menjadi akseptor KB pria } & \multirow{2}{*}{\multicolumn{2}{|c|}{ Jumlah }} & \multirow[t]{3}{*}{$p$ value } \\
\hline & & \multicolumn{2}{|c|}{ Kondom } & \multicolumn{2}{|c|}{ Vasektomi } & & & \\
\hline & & $\mathrm{N}$ & $\%$ & $\mathrm{~N}$ & $\%$ & $\mathrm{~N}$ & $\%$ & \\
\hline 1 & Tinggi & 17 & 74 & 6 & 26 & 23 & 100 & \multirow{3}{*}{0,006} \\
\hline 2 & Rendah & 28 & 100 & 0 & 0 & 28 & 100 & \\
\hline \multicolumn{2}{|c|}{ Total } & 45 & 88,2 & 6 & 11,8 & 51 & 100 & \\
\hline
\end{tabular}

Berdasarkan hasil uji Chi-Square untuk variabel pendidikan suami yang didapatkan $p$ value $(0,006) \leq \alpha(0,05)$, hal ini menunjukan bahwa secara statistik ada hubungan yang bermakna antara pendidikan suami dengan keikutsertaan suami menjadi akseptor KB pria di Wilayah Kerja Puskesmas Talang Betutu Palembang tahun 2017.

\section{PEMBAHASAN}

Berdasarkan tabel tentang Pekerjaan di Wilayah Kerja Puskesmas Talang Betutu Palembang, dari 51 responden terbagi menjadi dua kategori yaitu responden yang bekerja sebanyak 30 responden $(58,8 \%)$, sedangkan responden yang tidak bekerja sebanyak 21 respoden $(41,2 \%)$. Berdasarkan hasil Uji Chi-Square untuk 
variabel pekerjaan suami yang didapatkan $p$ value $(0,036) \leq \alpha(0,05)$, hal ini menunjukan bahwa secara statistik ada hubungan yang bermakna antara pekerjaan suami dengan keikutsertaan suami menjadi akseptor $\mathrm{kb}$ pria di Wilayah Kerja Puskesmas Talang Betutu Palembang Tahun 2017.

Pekerjaan adalah suatu yang dikerjakan untuk mendapatkan nafkah atau pencarian. Masyarakat yang sibuk dengan pekerjaan atau kegiatan sehari-hari akan memiliki waktu yang sedikit untuk memperoleh informasi. Dengan adanya pekerjaan seseorang memerlukan banyak waktu dan memerlukan banyak perhatian. Masyarakat yang sibuk hanya memiliki sedikit waktu untuk memperoleh informasi sehingga pengetahuan yang mereka peroleh kemungkinan juga berkurang. Bekerja Pegawai Negeri Sipil (PNS), Pegawai Honorer, Pegawai Swasta, Petani, dan Wiraswasta. Tidak bekerja Ibu Rumah Tangga (IRT) (Nursalam, 2008).

Berdasarkan tabel 5.5 tentang Pendidikan di Wilayah Kerja Puskesmas Talang betutu Palembang, dari 51 responden terbagi menjadi dua kategori yaitu responden yang berpendidikan tinggi sebanyak 23 responden (45\%), sedangkan responden yang berpendidikan rendah sebanyak 28 responden (55\%). Berdasarkan hasil uji Chi-Square untuk variabel pendidikan suami yang didapatkan $p$ value $(0,006) \leq \alpha(0,05)$, hal ini menunjukan bahwa secara statistik ada hubungan yang bermakna antara pendidikan suami dengan keikutsertaan suami menjadi akseptor $\mathrm{kb}$ pria di Wilayah Kerja Puskesmas Talang Betutu Palembang tahun 2017.

Pendidikan adalah suatu proses pertumbuhan dan perkembangan manusia, usaha mengatur pengetahuan semula yang ada pada seseorang individuitu. Pendidikan menjadi tolak ukur yang penting dan manfaat menentukan status ekonomi, status sosial, dan perubahan-perubahan positif (Notoatmodjo, 2012).

\section{Kesimpulan}

Dari hasil penelitian yang dilakukan di Puskesmas Talang Betutu Palembang Tahun 2017 dengan sampel 51 responden. Maka dapat diambil kesimpulan sebagai berikut :

1. Distribusi frekuensi berdasarkan keikutsertaan suami menjadi akseptor KB Pria Kondom sebanyak 45 responden sebesar $88,2 \%$ lebih besar dibandingkan dengan akseptor $\mathrm{KB}$ pria Vasektomi sebanyak 6 responden sebesar $11,8 \%$.

2. Distribusi frekuensi berdasarkan Pekerjaan yang bekerja sebanyak 30 responden sebesar 59\% lebih sedikit dibandingkan dengan suami yang tidak bekerja sebanyak 21 responden sebesar $41 \%$.

3. Distribusi frekuensi berdasarkan Pendidikan tinggi sebanyak 23 responden sebesar $45 \%$ lebih rendah dibandingkan dengan suami yang berpendidikan rendah sebanyak 28 responden sebesar $55 \%$.

4. Ada hubungan yang bermakna antara pekerjaan suami dengan keikutsertaan suami menjadi akseptor KB Pria dengan $p$ value 0,036 .

5. Ada hubungan yang bermakna antara pendidikan suami dengan keikutsertaan suami menjadi akseptor KB Pria dengan $p$ value 0,006 .

\section{Saran}

Dari hasil penelitian ini diharapkan kepada peneliti yang akan datang dapat memiliki variabel lain yang berhubungan dengan keikutsertaan suami menjadi 
akseptor KB Pria, serta lebih menggali lagi faktor-faktor yang berhubungan dengan keikutsertaan suami menjadi akseptor KB Pria.

\section{DAFTAR PUSTAKA}

BKKBN Pusat. 2007. Pedoman Pelaksanaan Pelayanan Kesehatan Dasar, Pemerintah swasta dan LSM Dalam Pelayanan KB Tahun 2007. Direktorat Jaminan dan Pelayanan KB. Jakarta Pusat.

BKKBN. 2015. Pedoman Pelaksanaan Pelayanan Kesehatan Dasar, Rumah Sakit Pemerintah swasta dan LSM Dalam Pelayanan KB Tahun 2015. Direktorat Jaminan dan Pelayanan KB. Jakarta.

Daniel. 2011. Keluarga Berencana. (online). Diakses pada 05 juni 2017.

Dinas Kesehatan Kota Palembang. 2014. Data Penggunaan Alat Kontrasepsi Pria Kota Palembang.

Dinas Kesehatan Kota Palembang. 2015. Data Penggunaan Alat Kontrasepsi Pria Kota Palembang.

DinkesRI. 2007 . Data SDKI Indonesia.Available:http://www.di nkesjateng prov.co.id. Diakses tanggal 01 Juni 2011.

DinkesRI. 2003. Data SDKI Indonesia. Available:http://www.dinkesjateng prov.co.id. Diakses 2010.

Gabriel. 2015. Hubungan Antara Pekerjaan dan Pendidikan Terhadap

Partisipasi Suami Menggunakan KB. http//poltekes-manado.ac.id//. Diakses pada tanggal 25 mei 2016.
Green, L, W., dan Kreuter, Marshall W. 2005. Health Program Planning, An Education And Ecological Approach (4th ed.). New York: the McGrawhill Companies

Hartanto, Hanafi. 2004. Keluarga Berencana dan Kontrasepsi. Jakarta: Pustaka Sinar Harapan.

Herman. 2012. Pelayanan Keluarga Berencana. Jakarta: ECG.

Hidayat, A. 2014. Metode Penelitian dan Tehnik Analisis Data. Jakarta Selatan : Salemba Medika.

Kurniawaty, Titik, dkk. 2013. Kependudukan dan pelayanan KB. Jakarta: ECG.

Kusmarjadi. 2009. Keluarga Berencana dan Kontrasepsi. Jakarta: Salemba Medika.

Mulyani, Nina Siti. 2013. Keluarga Berencana dan Alat Kontrasepsi. Yogyakarta: Nuha Medika.

Notoatmdojo, S. 2012.Metode Penelitian Kesehatan. Jakarta: Rineke Cipta.

Notoatmdojo, S. 2013.Metode Penelitian Kesehatan. Jakarta: Rineke Cipta.

Notoatmdojo, S. 2014.Metode Penelitian Kesehatan. Jakarta: Rineke Cipta.

Noviawaty, Dyah, dkk. 2009. Panduan Lengkap Pelayanan KB Terkini. Yogyakarta: Nuha Medika.

Nursalam. 2008. Keluarga Berencana Dan Kontrasepsi. Jakarta: Salemba Medika.

Profil Puskesmas Talang Betutu. 2016. Data Pengguna Akseptor KB Pria Tahun 2016. Palembang. 
Soekamto. 2002. Konsep Pendidikan. Jakarta: EGC.

Siswosudarmo. 2007. Keluarga Berencana dan Alat Kontrasepsi. Jakarta: Nuha Medika.

Saifudin,A.B. 2010. Buku Panduan Praktis Pelayanan Kontrasepsi. Jakarta: Yayasan Bina Pustaka Sarwono Prawirohardjo.

Sulistyawati, Ari. 2011. Pelayanan Keluarga Berencana. Jakarta: Salemba Medika.

Sulistyawati, Ari. 2016. Pelayanan Keluarga Berencana. Jakarta: Salemba Medika.

Yuhedi. 2013. Keluarga Berencana. Jakarta : Pustaka Sinar Harapan. 